\title{
Index to Vol. 64 (2003)
}

\section{Compiled by Kathy L. (Kit) Dusky}

$\mathbf{A}$

Abdulla, Ali D., "Eight steps for developing a first-year English composition award: a look at a successful program at East Carolina University" \& photo., 238-40

"About the guidelines," ACRL, 403, 470, 673

"Academic and research library campaign to launch during ACRL National Conference," 6

"Academic community is focus of new (a) your library campaign," 6

Academic or Research Librarian of the Year Award, 2003, $261 ; 2004,541$

Acquisitions (by institution): Appalachian State U., 558; Brooklyn Coll., 766; CSU (Northridge, 683 (\& photo); Sacramento, 683); Chicago Botanic Garden, 47; Emory U., 47, 212, 558; Georgetown U., 766; Hampshire Coll., 418-19; Harvard U., 278; Houston Academy of MedicineTex. Medical Ctr., 629-30; Knox Coll., 419 (\& photo.); Marshall U., 630; NYPL, 346, 683; NYU, 481, 766; Saint Michael's Coll., 419; San Diego State U., 212, 683; Schomburg Ctr., 630; State U. of W. Ga., 212; SUNY, Plattsburgh, 47; Tex. A\&M U., 557-58; UC (Berkeley, 481; San Diego, 558; Santa Barbara, 346, 629, 766; Santa Cruz, 122); U. of Del., 212; U. of Md., 629; U. of Mont., 558; U. of Nev, 278; U. of Or., 481; U. of Pittsburgh, 766; U. of S.C., 346; Yale U., 419

\section{Guide to index}

Fming is word-by-word (ALA, 1968).

AbBreviations: Standard abbreviations are used except in titles. Names of some organizations, ALA, ACRL, LC, etc., are also abbreviated and are alphabetized as if spelled out.

SPEClal abBreviations:

$\begin{array}{ll}\text { appt. } & \text { appointment } \\ \text { f. } & \text { foundation } \\ \text { port. } & \text { portrait } \\ \text { prof. } & \text { profile } \\ \text { prog. } & \text { program }\end{array}$

SPECIAI USAGES: More than one reference per page is indicated in parentheses. Under the heading "Acquisitions (by author, subject, or title)" parentheses may enclose donors' names (for subjects) or subjects (for named collections).
"Addendum to ACRL members running for ALA Council," 237

"Adventure, mystery, romance, and LCSH!" \& photos., Mizzy, 14-15, correction, 77

"Africa Action" \& logo, rev, of, 478

Agenbroad, James, retired, 280

"Agriculture Network Information Center " \& logo, rev. of, 203

Aldrich, Duncan, news note, 482

Alexander, Adrian W., "Two years after the launch: an update on the BioOne electronic publishing initiative," $652-55$

Allen, Bryce L., deceased \& port., 485

Allen, Nancy M., revs. ("The Martin Luther King Jr. Papers Project", 760; "National Center for Health Statistics" \& $\operatorname{logo}, 118)$

Alpi, Kristine M., "Criminal investigation and forensic science: sources for scholars and aficionados" \& logos, 590-93, 609

Amer. Antiquarian Soc., Leab Award, 325

"American Folklife Center: the Library of Congress" \& logo, rev. of, 624

ALA, Annual Conference, 2003, "ACRL Board of Directors' actions, June 2003: highlights of the Board's annual conference meetings" \& photos., 518-21; "ACRL in Toronto: ACRL programs at the ALA Annual Conference" \& photos., 509-16, 521; "ACRL programs \& meetings," AC-1-AC-16 (no.5); "Instruction Section to offer preconference in Toronto," 76, 237; "2003 ALA Annual Conference audiotapes now available, " 511

ALA, Midwinter Meeting, 2003, "ACRL at the Midwinter Meeting: actions of the ACRL Board of Directors," 16870; "Meet the ACRL Board," 38

ALA, Midwinter Meeting, 2004, "ACRL Discussion Groups," 715; "ACRL midwinter meetings in San Diego: a tentative schedule," 713-19; "ACRL offering three workshops at Midwinter," 650; "Celebrate 15 years of Information Literacy," 719; "Don't miss the ACRL President's Discussion Forum," 714; "In a Tropical Garden was created to promote the Panama-California Expedition held in San Diego in 1915," a postcard, 701 (photo., cover, no. 11); "Meet Alire and Kratz-candidates for ACRL President," 718; "The PATRIOT Act and higher education," 717; "Share your ideas with the ACRL Board," 716

"ALA/ACRL encourage participation of RoweCom creditor committee," 147

"ALA extends subscriptions to Divine/Rowecom customers," 76

"AlA signs agreement to mitigate RoweCom library losses," 236

"ALA TechSource offers combined subscriptions," 441-42

\section{About the author}

Kathy L. (Kit) Dusky is cataloger/associate professor at Portland State University, e-mail: duskyk@pdx.edu 
"American Political Science Association announces new journal," 368

"An application profile and prototype metadata management system for licensed electronic resources," Chandler, 405,705

"Apply for Immersion '04," 588

"Apply for Immersion '04, July 30 to August 4, 2004," 648 Appointments, 48-49, 124-25, 214-16, 279-80, 348-49, 420$21,483-84,560-61,631-33,685-87,769-70$

"Archives and special collections: a guide to resources on the Web" \& logos, Zanish-Belcher, 163-66

"Archives and special collections: 24/7," Brown, 440

Argentati, Carolyn, appt., 631; news note \& port., 420

"Assessment of reference instruction as a teaching and learning activity: an experiment at the University of Illinois-Springfield," Green, 256-58

"Assoc. Colleges of the South creates online journal," 300

"ALCTS metadata task force report available," 505

ACRL, Academic or Research Librarian of the Year Award, 2003, 261; 2004, 541; "Addendum to ACRL members running for ALA Council," 237; "ALA/ACRL encourage participation of RoweCom creditor committee," 147 ; "And the winners are ... the official results of the 2003 ACRL elections," 398-401; "Apply for Immersion '04, July 30 to August 4, 2004," 648; "@ your library toolkit will help you market your library," 370 ( $\&$ photo.); Doctoral Dissertation Fellowship, 2003, 262; 2004, 542; "Don't be left out: sign up for ACRL e-mail updates," 89 "Don't forget the Forum," 506; "Dumont and Maloy share plans for ACRL: vote in the election this spring," 102-6; Excellence in Academic Libraries Award, 2003, 260, 262; 2004, 541; "Friends of ACRL," 751; "Get involved with ACRL: volunteer to serve on a division or section committee, 599-601; "Guidelines Regarding Thefts in Libraries makes literary debut," 299; "Harvard Leadership 2003," 91; Hugh C. Atkinson Memorial Award, 2003, 324; 2004, 541; "It's coming! New ACRL Web site to launch in April," 148; "It's not just academic @ your library: the Campaign for America's Libraries Academic and Research Library Campaign" \& photo., 159-60 "Leaming to Make a Difference: Proceedings of the ACRL 11th National Conference is available," 401; "Meet the candidates for ALA president: vote in the election this spring" \& ports., 182-88; "Meet the staff," 752-55; "Members-only content now available on ACRL Web site," 504; "Members running for ALA Council," 190; "Membership statistics," 735; "New monograph titles for 2002-03," 742; "Participate in the ACRL strategic planning process," 505; "Register now for the ACRL/ Harvard Leadership Institute August 3-8, 2003, Cambridge, Massachusetts," 302, 370; "Section committee volunteer form," 603; "Share your effective practices through ACRL's clearinghouse," 703; "Share your library's effective practices through ACRL clearinghouse," 150; "Sponsorships for 2003," 727; "Subscribe to ACRL e-mail updates," 336; "Those immersed resurface: a follow up with Track 2 participants of the first Information Literacy Immersion," 17-19; "2003-04 ACRL chapter conferences/events," 604-5; "Year in review," 731-44

ACRL, Annual Conference, 2003, "Conference programsToronto," 2003, 729; "Instruction Section to offer preconference in Toronto," 76, 237; "Preconferences," 2003, 738; "2003 ALA Annual Conference audiotapes now available," 511

ACRL, Annual Conference, 2004, "ACRL offering three workshops at Midwinter," 650; "In a Tropical Garden was created to promote the Panama-Califomia Expedition held in San Diego in 1915," a postcard, 701 (photo., cover, no. 11)

ACRL, Annual report, 2002-2003, 725

ACRL, Board of Directors, "Highlights" (Jan., 168-70; June \& photos, 518-21); "Meet the ACRL Board," 38; photo. \& roster, 2002-03, 745
ACRL, Budget \& Finance Comm. Chair, "Financial report" \& port., 746-50

ACRL, College and Research Libraries Standards Task Force, "Hearing on the 'Standards for Libraries in Higher Education", 331; "Standards for libraries in higher education," a draft, 329-36

ACRL, Comm. on the Status of Academic Librarians, "About the guidelines," 673; "A guideline for the screening and appointment of academic librarians using a search committee," final draft, 672-73

ACRL, GICLS, Community College Leaming Resources/Library Achievement Awards, 2004, 542; Community College Learning Resources/Library Achievement Awards, 2003, 327

ACRL, DLS, "Guidelines brochures available online," 271 ; "Guidelines for distance learning library services," draft revision", 265-71; "Revising the guidelines," 266-67

ACRL, EBSS, "About the guidelines," 470; Distinguished Education and Behavioral Sciences Librarian Award, 2004, 542; Distinguished Education and Behavioral Sciences Librarian Award, 2003, 326; "Guidelines for curriculum materials centers," approved 2003, 469-74

ACRL, Exec. Director, "Letter" \& port., 730-31

ACRL, Institute for Information Literacy, "Characteristics of programs of information literacy that illustrate best practice," a draft, 32-35; "Characteristics of programs of information literacy that illustrate best practices: a guideline," approved 2003, 544-47; "History," 33, 545; "Those immersed resurface: a follow up with Track 2 participants of the first Information Literacy Immersion," 17-19

ACRL, IS, "Characteristics of programs of information literacy that illustrate best practice," a draft, 32-35; "Finally, guidelines!", 617; "Guidelines for instruction programs in academic libraries, approved 2003, 616-19; "History," 33, 109; Innovation in Instruction Award, 2003, 327; 2004, 542; Instruction Section Publication of the Year Award, 2003, 325; 2004, 542; "Instruction Section to offer preconference in Toronto," 237; Miriam Dudley Instruction Librarian Award, 2003, 262-63; 2004, 542; "Panel session," 111; "Research agenda for library instruction and information literacy," updated version, 108-13

ACRL ${ }_{1}$ L.PSS, Marta Lange/CO Award, 2003, 263; 2004, 54142

ACRL, Midwinter meeting, 2003, "ACRL at the Midwinter Meeting: actions of the ACRL Board of Directors," 168 70; "Workshops @ Midwinter Meeting," 739

ACRL, Midwinter meeting, 2004, "ACRL Discussion Groups," 715; "Celebrate 15 years of Information Literacy," 719; "Don't miss the ACRL President's Discussion Forum," 714; "Meet Alire and Kratz-candidates for ACRL President," 718; "Meetings in San Diego: a tentative schedule," 713-19; "The PATRIOT Act and higher education," 717; "Share your ideas with the ACRL Board," 716

ACRL, National Conference, 2003, "Academic and research library campaign to launch during ACRL National Conference," 6; "ACRL invites you to join its 11th National Conference in Charlotte, April 10-13, 2003," 145 (photo., cover, no. 3); "Audiocassettes/CDs available," 444; "The Carolinas' rich library legacy: touring Charlotte-area libraries at the ACRL National Conference" \& photos., Tierney, 80-83; "Charlotte nights: what to do at the end of the conference day" \& photos., Tierney, 179-181; "Charlotte on the Web," Tienney, 180; "Leaming to make a difference: Charlotte, North Carolina, April 10-13: preliminary program" \& photos., C-1—C-28 (no.1); "Learning to make a difference: coverage from ACRL's 11th National Conference, part 1 " \& photos. \& ports., 372-377, 409; "Learning to make a difference: coverage from ACRL's 11th National Conference, part 2" \& photos., 443-88, 454; "Proceedings available," 377; "Take a ride on this charming trolley when you visit Charlotte, North 
Carolina," 3 (photo., cover, no. 1); "Transportation information," Tierney, 181; "Webcasts of ACRL National Conference programs available," 299

ACRL, National Conference, 2005, "Call for participation: Minneapolis National Conference," insert (no. 10)

ACRL, President, "Message" \& port., 726-27

ACRL, RBMS, "About the guidelines," 403; "Guidelines regarding thefts in libraries," approved 2003, 402-7; Katharine Kyes Leab and Daniel J. Leab American Book Prices Current Exhibition Catalogue Awards, 2003, 32526; 2004, 542; "Richard Clement named editor of RBM," 149

ACRL, Scholarly Communication Committee, "Principles and strategies for the reform of scholarly communication: issues related to the formal system of scholarly communication," 526-27, 547

ACRL, STS, Eunice Rockwell Oberly Award, 2003, 326

ACRL, TLT Group, "Register now for 'Information Literacy and Assessment' online seminar," 457

ACRL, ULS, "News from the University Libraries Section: a wrap-up of activities at Midwinter," 254-55

ACRL, Vice-President, "Message" \& port., 728-29

ACRL, WESS, Coutts Nijhoff International West European Specialist Study Grant, 2003, 326-27; 2004, 542; "Join WESS in Paris in March 2004," 584

ACRL, WSS, Career Achievement in Women's Studies Librarianship, 2003, 263; 2004, 542; Significant Achievement in Women's Studies Librarianship, 2003 , $263 ; 2004,542$

"ACRL and TLT Group offer second installment in information literacy seminar series," 237

"ACRL at the Midwinter Meeting: actions of the ACRL Board of Directors," 168-70

"ACRL award winners, 2003,"733

"ACRL candidates for 2003: see who's running for office.", 28-31

"ACRL committee volunteer form," 602

"ACRL creates first-year experience task force," 706

"ACRL Discussion Groups," 715

"ACRL environmental scan available online to members," Cary, 300-301

"ACRL/Harvard Leadership Institute," 302, 370

"ACRL/Harvard Leadership Institute: highlights from the fourth annual institute," Gilreath, 90-91

"ACRL honors the 2003 award winners: a recognition of professional achievement," Sherrod, 260-63

"ACRL honors the 2003 award winners: the final installment of ACRL award winners," Sherrod, 324-27

"ACRL in Toronto: ACRL programs at the ALA Annual Conference" \& photos., 509-16, 521

"ACRL invites you to attend the 2003 ACRL/Harvard Leadership Institute," 236

"ACRL invites you to join its 11th National Conference in Charlotte, April 10-13, 2003," 145 (photo., cover, no. 3)

"ACRL journals," 741

"ACRL launches @ your library discussion list," 235

"ACRL midwinter meetings in San Diego: a tentative schedule," 713-19

"ACRL offering three workshops at Midwinter," 650

"ACRL offering two online seminars this fall," 542

"ACRL President Helen H. Spalding signed a cross-border agreement" photo, 504

"ACRL programs \& meetings," AC-1-AC-16 (no.5)

"ACRL sponsoring LearningTimes Library Online Conference: members receive $\$ 50$ registration discount," 586

ACRL Standards \& Guidelines ("About the guidelines," 403, 470, 673; "Characteristics of programs of information literacy that illustrate best practice," a draft, 32-35; "Characteristics of programs of information literacy that illustrate best practices: a guideline," approved 2003, 544-47; "Finally, guidelines!", 617; "A guideline for the screening and appointment of academic librarians using a search committee," final draft, 672-73; "Guidelines brochures available online," ACRL, 271; "Guidelines for curriculum materials centers," approved 2003, 469-74; "Guidelines for distance learning library services," ACRL, draft revision, 265-71; "Guidelines for instruction programs in academic libraries, approved 2003, 616-19; "Guidelines regarding thefts in libraries," approved 2003, 402-7; "Hearing on the "Standards for Libraries in Higher Education", 331; "History," 33, 109, 545; "Panel session," 111; "Research agenda for library instruction and information literacy," updated version, 108-13; "Revising the guidelines," ACRL, 266-67; "Standards for libraries in higher education," a draft, 329-36)

"ACRI's 2004 awards program: honoring outstanding achievements in academic librarianship" \& photo., Petrowski, 541-42

"ACRL's e-Learning Webcasts ... just a click away," 442

"ACRL's mission," 725

ASERL, "UNC Charlotte joins ASERL's Kudzu project," 150

"ASERL launches shared chat reference service," 503

"ASERL opens programs to nonmember libraries," 75

(a) your library Toolkit for Academic and Research Libraries, published, ACRL, 370 (\& photo.)

"(0) your library toolkit will help you market your library," ACRL, 370 (\& photo.)

"(6) your library at the ACRL National Conference," 6

Atkinson, Ross, "Named Academic/Research Librarian of the Year" \& port., 233, 261 (port., cover, no. 4); photo., 514

Atkinson (Hugh C.) Memorial Award, 2003, 324; 2004, 541

Attanasi, Meagan, photo., 239

Aubum U., "Diversity: it's not just the right thing to do," $594-95,605$

"Audiocassettes/CDs available," 444

Awards, 74-5, 260-63 (8), 324-27 (9), 541-52 (15), 733

B

Baker, William, news note, 348

Baker \& Taylor, Academic or Research Librarian of the Year Award, 2003, 261; 2004, 541

Balderrama, Sandra Rios, news note \& port., 631

Barczyk, Ewa, appt., 685

Bard, Scott, photos., 541, correction, 585

Barnes, Shcrri, "WSS Significant Achievement Award goes to Barnes," 263

Barreau, Deborah, news note, 123

Bartosz, Kimberly, rev. ("National Partnership for Women \& Families" \& logo), 342

Baruch Coll., "Excellence in Academic Libraries winners announced," 260

Batemen, Betzi L., "Educational technology: a guide to resources on the Web" \& logos, 9-12

Baton Rouge Community Coll," "Carr and Baton Rouge Community College win CJCLS awards, 327

Beall, Jeffrey, "How successful is copy cataloging at catching and fixing typographical errors in records imported from bibliographic utilities?", 704

Beck, Sheila, rev. ("Education World"), 274

Bell, Steven J., "Stop sending those cards: enhancing facultylibrarian collaboration using e-selection strategies," 6069

Berring, Robert, appt. \& port., 214

"The bewildering new world of scholarly communication: helping faculty understand the issues," Dess, 242-245

Bibliocentre, "Sirsi selected by Bibliocentre," 301

Bielefeld, Megan, port., 752

Billings, Harold, retired \& port., 216

BioOne, "Two years after the launch: an update on the BioOne electronic publishing initiative," $652-55$

Black, Fiona, appt., 348

Blackwell's Book Services, Excellence in Academic Libraries Award, 2003, 260, 262; 2004, 541

"Blackwell's Online Bookshop gets a makeover," 370

Bleiler, Richard, news note, 482

"Blue Lady" was designed for the cover of the Stone and Kimball publication The Chap-Book, Bradley, 581 (photo., cover, no. 9) 
Blum, Robert, "A street corner in San Francisco's China Town, circa 1890," 437 (photo., cover, no. 7)

Bowling Green State U., "Adventure, mystery, romance, and LCSH!" \& photos., 14-15, correction, 77; "Jerome Rollers, a newly formed library drill tearn, performing in the Bowling Green State University Holiday Parade" photo., 14, correction, 77; "Popular culture cataloger and reference librarian," 15

Bradley, Lynne E., "Washington hotline," 198, 272, 338 , $409,475,549,620,674,756-57,771$

Bradley, Will, "Blue Lady" was designed for the cover of the Stone and Kimball publication The Chap-Book, 581 (photo., cover, no 9)

Brey, Carol, "Meet the candidates for ALA president: vote in the election this spring" \& port., 182-88

Brigham Young U., "Widespread academic efforts address the scholarly communication crisis: the results of a survey of academic institutions, 382-83, 389

"Bringing history to life" \& port., Mizzy, 596-97

"British library opens collections for electronic delivery," 442

Browar, Lisa, appt., 124

Brown, Barbara, retired \& port., 561

Brown, Doris R., "Collection disaster: mold in the stacks," 304-6

Brown, William, "Archives and special collections: 24/7," 440

Brunk, Charles, retired, 125

Buck, Anne M., deceased \& port., 421

Buhr, Rosemary E., retired, 633

Burk, Teresa, news note, 123

Burke, Gerald T., "There's money out there for you: writing personal grants," 155-57, 170

Burke, Jane, news note, 123

"Burke Library to join Columbia," 302

Burnette, Liz, news note, 560

Busch, Nancy, appt., 631

Buschman, John, news note, 768

Byrd, Theresa S., photos., 518, 745

C

CSU, "Integrating information literacy into the learning outcomes of academic disciplines: a critical 21st-century issue, ${ }^{\prime 6} 612-15$

CSU, Northridge, "Who's afraid of partnerships for information literacy initiatives? Working together to empower learners," 246-48, 253

"Call for papers: Popular Culture Association 2004," 584

"Call for participation: Minneapolis National Conference," ACRL, National Conference, 2005, insert (no. 10)

Cammarata, Paul \& Clo, "Photojournalism on the Web: a guide for practicing and student photojoumalists" \& logos, 451-54

Canadian Association of College and University Libraries (CACUL), "ACRL President Helen H. Spalding signed a cross-border agreement" photo., 504

"Canadian National Site Licensing Project chooses Science Direct," 237

Cannon, Tyrone H., ACRL president \& port., 398-99; "The learning community as knowledge builders: the 2003 04 ACRL President's theme," 533-35; "Message from the vice-president" \& port., 728-29; photos., 377, 510, $518,520,745$

Career Achievement in Women's Studies Librarianship, 2003 263; 2004, 542

Carney, Kathleen, photo., 510

"The Carolinas' rich library legacy: touring Charlotte-area libraries at the ACRL National Conference" \& photos. Tierney, 80-83

Carr, Mary, "Carr and Baton Rouge Community College win CJCLS awards, 327

Carroll-Hackett, Mary, photo., 239

Cartoons, 5, 75, 147, 235, 299, 367, 439, 503, 583, 647 703
Cary, Shannon, "ACRL environmental scan available online to members," $300-301$; port., 752

Cawthorne, Jon E., "Integrating outreach and building partnerships: expanding our role in the learning community," 666-69, 681

"Celebrate 15 years of Information Literacy," 719

"A Celebration of Women Writers" \& logo, rev. of, 202-3

"Center for Applied Linguistics," rev. of, 274-75

"Center for Biologics Evaluation and Research" \& logo, rev of, 552

"Center for History and New Media" \& logo, rev. of, 118-19

Central Mich. U., "When the library becomes the largest computer lab on campus: supporting productivity software in an academic environment," 462-64, 468

Chabot, Lisabeth, appt., 631

Chandler, Adam, "An application profile and prototype metadata management system for licensed electronic resources," 405, 705

Channing, Rhoda, deceased \& port., 561-62

Chapel, Robert, deceased \& port., 50

"Characteristics of programs of information literacy that illustrate best practice," ACRL, a draft, 32-35

"Characteristics of programs of information literacy that illustrate best practices: a guideline," ACRL, approved 2003, 544-47

"Charlotte nights: what to do at the end of the conference day" \& photos., Tierney, 179-181

"Charlotte on the Web," Tierney, 180

Cheng, Yungrang Laura, "Receives Doctoral Dissertation Fellowship" \& port., 262

Chmelir, Lynn, "Got a secret? Pass it on ...: recruiting new librarians," 395-97; "Recruiting for librarianship," 396

"CHOICE offers compilation of Outstanding Academic Titles", 505

City Coll. of San Francisco, "Fxcellence in Academic Libraries winners announced," 260; "Pan American Unity," two panels from the mural, Rivera, 501 (photo., cover, no. 8)

City of San Jose, "First joint city/university library opens its doors," 503

CUNY,Queensborough Community Coll., "Multilingualism at the reference desk: keeping students connected," $322-23,336$

"Civilrights.org: the Progressive Coalition for Equal Opportunity" \& logo, rev. of, 119

Clark, Susan E., rev. ("U.S. Institute of Peace" \& logo), 414

"Classical Music Library offers charter subscription," 650

Clement, Richard W., "Named editor of RBM," 149; news note, 685

Coburn, Barbara, deceased, 280

Cochenour, Donnice, news note, 482

"Collection disaster: mold in the stacks," Brown, 304-6

CGRL Neus, "Statement of ownership and management," 655; "Viles steps down as 'Fast Facts' editor," 441

"CERL News seeks cartoonist," 503

"CERL News seeks "Fast Facts" editor," 149

"CERL News submission guidelines," 36

"College of DuPage hosts Russian librarians," 505-6

"College of New Rochelle Library named Project of the Year," 439

Coll. of the Holy Cross, Leab Award, 325

Columbia Coll., "ITW Library Skills Exchange," 709; "World Libraty Partnership" \& photo., 708-9, 709

"Columbia establishes digital program," 584

Columbia U., "Burke Library to join Columbia," 302; "DSpace Federation collaboration announced," 147; "Putin tours Columbia U. archive," 649-50

"Committee volunteer form," ACRL, 602

"Community, technical colleges choose Voyager," 648

Community College Learning Resources/Library Achievement Arvards, 2004, 542

Community College Learning Resources/Library Achievement Awards, 2003, 327 
"The community college library perspective in an age of opportunity: meeting expectations in times of uncertainty," Fradkin, 721-23

Conahan, Margot Sutton, port., 752

Conference circuit ("ACRL/Harvard Leadership Institute: highlights from the fourth annual institute," Gilreath, 90-91; "ACRL at the Midwinter Meeting: actions of the ACRL Board of Directors," 168-70; "ACRL Discussion Groups," 715; "ACRL in Toronto: ACRL programs at the AL.A Annual Conference" \& photos., 509-16, 521; "ACRI midwinter meetings in San Diego: a tentative schedule," 713-19; "Celebrate 15 years of Information Literacy," 719; "Don't miss the ACRL President's Discussion Forum," 714; "Meet Alire and Kratz-candidates for ACRL President," 718; "News from the University Libraries Section: a wrap-up of activities at Midwinter," Sherby, 254-55; "The PATRIOT Act and higher education," 717; "The President's Discussion Forum at Midwinter: exploring a world of values," Padley, 25253; "Share your ideas with the ACRL Board," 716)

CQ, Marta Lange/CQ Award, 2003, 263; 2004, 541-42

Conn. Coll., "CTW Library Consortium chooses Voyager," 439

Connolly, David, port., 752

Consales, Judy, news note, 48

Conway, Martha, photo., 211

Cornell U., "Diversity initiatives $v s$. residency programs: agents of change?, 308-10, 315; "DSpace Federation collaboration announced," 147

Corrections, $77,149,245,468,547,585$

Coughlin, Caroline, deceased, 770-71

"CLIR surveys audio collections," 299

Coutts Nijhoff International West European Specialist Study Grant, 2003, 326-27; 2004, 542

"The cover illustration is from the Marjorie Pickthall Manuscript Collections in the Special Collections of the Victoria University at the University of Toronto's E. J. Pratt Library," 297 (photo., cover, no.5)

"Criminal investigation and forensic science: sources for scholars and aficionados" \& logos, Alpi, 590-93, 609

"Crisis in foreign language expertise in research libraries: how do we fill this gap?", Kellsey, 391-92, 397

"CTW Library Consortium chooses Voyager," 439

"Culinary resources: cookery and culinary history Web sites" \& logos, Summerfield, 656-59

\section{D}

Daganaar, Mark L., appt. \& port, 279

Dancik, Deborah B., photos., 518, 520, 745

Daniel, Milton G. "Roy," deceased, 771

Danton, Joseph Periam, deceased, 50

Darbyshire, Jean, "Using an executive search firm to fill faculty library positions: one library's story," 523-25

Davis, Francie, deceased, 349

Davis, Mary Ellen K., "Letter from the executive director" \& port., 730-31; photos., 512, 518, 520, 745; port., 753

Deaths, $50,125,216,280,349,421,485,561-62,634,688$, $770-71$

Denholm, Patricia, appt. \& port., 685

DePaul U., "Collection disaster: mold in the stacks," 304-6; "World Library Partnership" \& photo., 708-9, 709

Desai, Christina M., "Getting cited: ten tips for practitioners of citation analysis in the library" \& photo., 21-23, 27

Dess, Howard M., "The bewildering new world of scholarly communication: helping faculty understand the issues," 242-245

"A detail from an illustration in the multivolume work Description de L'Égypte, ou Recueil des Observations ...", 73 (photo., cover, no. 2)

Dickstein, Ruth H., "Wins WSS Career Achievement Award" \& port., 263

"Digital projects manager," Mizzy, 597

Dillon, Dennis, "Strategies to keep the wolf from the door: collection development when the budget is tight," 536-37
Distinguished Education and Behavioral Sciences Librarian Award, 2004, 542

Distinguished Education and Behavioral Sciences Librarian Award, 2003, 326

"Diversity: it's not just the right thing to do," Goss, 594-95, 605

"Diversity initiatives $v s$, residency programs: agents of change?, Hankins, 308-10, 315

Doctoral Dissertation Fellowship, 2003, 262; 2004, 542

"Don't be left out: sign up for ACRL e-mail updates," 89

"Don't forget the Forum," 506

"Don't miss the ACRL President's Discussion Forum," 714

Douglas, Jeffrey, photo., 419

Down, Nancy, port., 14, correction, 77

Downer, Sheri, news note, 348

Drobnicki, John A., rev. ("EUROPARL: the European Parliament On-Line"), 552-53

Drost, Carol A., "Internet reviews," 42-43, 118-19, 202-3, $274-75,342-43,413-14,477-78,552-53,624-25,678-$ $79,760-61$

"DSpace Federation collaboration announced," 147

Dudley (Miriam) Instruction Librarian Award, 2003, 262-63: 2004,542

Duguid, Paul, port., 373

Dumont, Paul, ports., 28, 102-4

"Dumont and Maloy share plans for ACRL: vote in the election this spring," $102-6$

Dykhuis, Randy, news note, 482

"Dynix and YBP Library Services enter partnership," 302

"Dynix celebrates 20th anniversary," 583

"Dynix partners with Serials Solution," 706

Dyson, Allan J., retired, 484

\section{$\mathbf{E}$}

"E-poetry: digital frontiers for an evolving art form" \& logos, Shirkey, 249-51

E. Carolina U., "Eight steps for developing a first-year English composition award: a look at a successful program at East Carolina University" \& photo., 238-40

Eberhart, George M., "New publications," 44-45 (\& photos.), 120-21 (\& photo.), 206-8 (\& photo.), 277 (\& photo.) 344-45 (\& photo.), 416-17 (\& photo), 479-80 (\& photos.), 554-555 (\& photo), 626-27 (\& photos.), 680-81 ( \& photos.), 762-64 ( $\&$ photos.)

"Ebrary launches new database collections," 147

EBSCO, Community College Learning Resources/Library Achievement Awards, 2004, 542; Community College Learning Resources/Library Achievement Awards, 2003, 327

"EBSCO acquisition of RoweCom's U.S. and European operations approved," 367

"EBSCO to acquire RoweCom operations," 75

EBSCOhost, "Index browsing available through EBSCOhost," 647

"EBSCO's A-to-Z service now available," 441

"Education World," rev. of, 274

"Educational technology: a guide to resources on the Web" \& Iogos, Batemen, 9-12

Edwards, Tory, port., 753

"Eight steps for developing a first-year English composition award: a look at a successful program at East Carolina University" \& photo., Abdulla, 238-40

Eimas, Richard, retired, 50

"11th National Conference Proceedings available from ACRL," 401

Elmborg, James K., "Named IS Publication Award winner," 325

"Elsevier launches Library Connect," 7

Elsevier Science, Miriam Dudley Instruction Librarian Award, 2003, 262-63; 2004, 542

"Endeavor announces course content integrator," 506

"Endeavor releases ENCompass 3.0," 77

"Entering academic librarianship: tips for library school students," Singleton, 84-86, correction, 245 
Errata, 77, 149, 245, 468, 547, 585

Eunice Rockwell Oberly Award, 2003, 326

"EUROPARL: the European Parliament On-Line," rev. of, 552-53

Excellence in Academic Libraries Award, 2003, 260, 262; 2004, 541

$\mathbf{F}$

Farrell, Katharine, "Farrell \& Truitt awarded Lazerow Fellowship," 262; photo., 541

"Fast facts," Pattillo, 578, 642, 698, 790; Viles, 70, 138, 230, $294,362,434,498$

Faulkner, Lila, "K. G. Saur Award" \& photo., 326

Ferris, Bill, photo., 448 ; port. 375

Ferullo, Donna L., "Piracy on campuses: opportunity not problem," 664-65

Fescemyer, Kathy, "Horticulture: sources for gardeners," 312-15

"Finally, guidelines!", ACRL, 617

"First joint city/university library opens its doors," 503

Flake, Chad John, deceased, 771

Fong, Victoria, news note, 279

Ford, Barbara J., news note \& port., 214

Fosmire, Michael, "The LEADER project: becoming an information LEADER at Purdue University," 192-95

Fowler, Clara S., "Instructional leadership: new responsibilities for a new reality," 465-68, correction, 546

Fradkin, Bernard, "The community college library perspective in an age of opportunity: meeting expectations in times of uncertainty," 721-23

Frank, Donald G., "New relationships in academe: opportunities for vitality and relevance," 24-27

Frederiksen, Linda, revs. "Center for History and New Media" \& logo, 118-19; rev. "NationMaster.com" \& logo, 678)

Frey, Susan M., rev. ("Spine-health.com" \& logo), 413-14

Fridena, Betty, port., 458

"The Friends of the Minnesota Library hosted 'An Evening of Ribald Literature' to celebrate the groups' tenth anniversary in October" photo., 706

Frodin, David G., "STS Oberly Award goes to Frodin," 326

\section{G}

"Gale aligns reports to ICOLC and COUNTER guidelines," 442

"Gale introduces virtual reference database," 585

Galloway, Ann-Christe, "Grants and acquisitions," 47, 122 , $211-12,278,346,418-19,481,557-58,628-30,682-$ 83, 765-66; "People in the News", 48-50, 123-25, 214$16,279-80,348-49,420-21,482-85,560-62,631-34$, $685-88,768-71$; port., 753

"Gallup offers weekly briefing service," 7

Gard, Betty, news note, 48

Garrett, Marie, "Taking immersion home: applying lessons learned at ACRL's Immersion Program," 587-88, 609

Germain, Carol Anne, "There's money out there for you: writing personal grants," 155-57, 170

"Get involved with ACRL: volunteer to serve on a division or section committee, 599-601

"Getting cited: ten tips for practitioners of citation analysis in the library" \& photo., Desai, 21-23, 27

"Getting to know your subject specialty: add a little romance (literature) to your life," Ward, 318-20

Getty Research Inst., Leab Award, 325

Gilreath, Charles, "ACRL/Harvard Leadership Institute: highlights from the fourth annual institute," 90-91

"globalEDGE" \& logo, rev. of, 624-25

Goldeman, Gail, rev. ("Hoover Institution on War, Revolution and Peace"), 625

Gollop, Claudia, news note, 123

Goodmuth, Rebecca Lynn, photo., 239

Gorman, Larry, retired, 216

Goss, Harold, "Diversity: it's not just the right thing to do," 594-95. 605
"Got a secret? Pass it on ...: recruiting new libratians," Chmelir, $395-97$

Gotwals, Joan, retired \& port., 633

"GPO and NARA support permanent online access," 583

Graf, Francine, port., 753

Graham, Krista, "When the library becomes the largest computer lab on campus: supporting productivity software in an academic environment," 462-64, 468

Grant, Marilyn, deceased, 280

"Grants and acquisitions," Galloway, 47, 122, 211-12, $278,346,418-19,481,557-58,628-30,682-83$, $765-66$

Grants (by grantee): ATLA, 557; Atlanta U. Ctr., 682; Black Hawk Community Coll., 346; Burke Library, 302; CSU, Northridge, 418; Center for Research Libraries, 346; CUNY, Hostos Community Coll., 557; Clark Atlanta U., 682; Coll. Ctr. for Lib. Automation, 628; Columbia U., 211, 628-29, 765; Cornell U., 122, 212; Duke U., 557; E. Carolina U., 682; Emory U., 47; Fisk U., 557; Frank H. McClung Mus., 122; Ga. Institute of Technology, 122; Herzog August Bibliothek, Wofenbüettel, 122; HBCU, 628; Ill. State U., 346; Ind. U., 481; Johns Hopkins U., 47, 278, 418; Libraries for the Future, 557; Morehouse Coll., 682; Mount Holyoke Coll., 682; N.J. State Lib., 765; NY State Historical Assn., 278; NYU, 557, 628 Newberry Lib. \& photo., 211; N. Central Coll., 346; N.C. State U, 628-29, 765; Northeastern U., 211-12; Oberlin Coll., 682; Occidental Coll., 682; Ohio State U., 211; Ringling School of Art and Design, 278; Rutgers U., 122, 682-83, 765; Simmons Coll., 418; SOLINET, 628, 765; Spelman Coll., 682; Swarthmore Coll., 682; Tampa Bay Lib. Consortium, 628; Temple U., 122; UC (Davis, 211; Santa Barbara, 682); U. of Chicago, 628-29; U. of Ill., UC, 47, 122; U. of La., Lafayette, 628 ; U. of Pittsburgh, $278,346,418$; U. of SC, 418, 481; U. of Tenn., 122; U of Wash., 122; Wayne State U., 682; Wellesley Coll, 682; W. State Coll. of Colo., 122; Western Ill. U., 346; Willamette U., 47

Grants (by grantor): Apex, 682; Baird F., 278; Brach (John) alumnus, 122; Buhl F., 418; Delmas (Gladys Krieble) F., 122; Ford F., 212; Gates (Bill \& Melinda) F., 418, 557; Haynes (John Randolph \& Dora) F., 418; Humbold (Alexander von) F. TransCoop, 122; Ill. State Lib., 211; IMLS, 47, 122 (2), 211, 278, 682, 765; LSTA, 211-12 (2), 346, 628; La. Bd. of Regents Traditional Enhancement Grant 628; Luce (Henry) F., 346; Mellon (Andrew W.) F., 302, 481, 628, 682, 765; Meyer Memorial Trust, 47; Moran (William R.) donation, 682; Natl. Film Preservation F., 481, 557; NEA, 557; NEH, 47, 418 (2), 557, 628, 682-83; NHPRC, 557; NSF, 122, 765; Pew Charitable Trusts, 122; Pittsburgh F., 418; Ringling School Library Assn, 278; Rockefeller F., 211; Save America's Treasures, 211, 278; Simpson (Robert \& Juanita) Endowment, 47; USDE, 628-29

Green, Denise D., "Assessment of reference instruction as a teaching and leaming activity: an experiment at the University of Illinois-Springfield," 256-58

Greenberg, Charles J., news note, 48

Greenwood Publishing, Career Achievement in Women's Studies Librarianship, 2003, 263; 2004, 542

"A guideline for the screening and appointment of academic librarians using a search committee," ACRL, final draft, 672-73

"Guidelines brochures available online," ACRL, 271

"Guidelines for curriculum materials centers," ACRL, approved $2003,469-74$

"Guidelines for distance learning library services," ACRL, draft revision, 265-71

"Guidelines for instruction programs in academic libraries, ACRL, approved 2003, 616-19

"Guidelines regarding thefts in libraries," ACRL, approved 2003, 402-7

"Guidelines Regarding Thefts in Libraries makes literary debut," ACRL, 299 


\section{$\mathbf{H}$}

Hahn, Bessie King, news note, 420

Hahn, Karla, "K. G. Saur Award" \& photo., 326

Hahn, Suzan, port., 316

Hahn, Trudi Bellardo, news note \& port., 768

Hampshire Coll., "Massachusetts Center for the Book celebrates books, reading, and libraries," 235

Hankins, Rebecca, "Diversity initiatives $v$ s. residency programs: agents of change?, 308-10, 315

Hannaford, William, news note, 768

Hardesty, Carol, photo., 374

Hardesty, Larry, photos., 372, 374, 377, 444

Hartsook, Herbert J., appt. \& port., 483

Harvard Business School, "Harvard's Baker Library prepares for renovation," 300-301

Harvard Coll., "Takes reference on the road" \& photo., 441

Harvard Institues for Higher Education, "Harvard Leadership $2003, " 91$

Harvard Institutes for Higher Education, "ACRL/Harvard Leadership Institute: highlights from the fourth annual institute," 90-91; "ACRL invites you to attend the 2003 ACRL/Harvard Leadership Institute," 236; "Register now for the ACRL/Harvard Leadership Institute August 3-8, 2003, Cambridge, Massachusetts," 302, 370

"Harvard Leadership 2003," ACRL, 91

"Harvard's Baker Library prepares for renovation," 300-301

Hawk, Ben, port., 754

"Haworth Press introduces electronic access for all joumals," 504

"Hearing on the 'Standards for Libraties in Higher Education", ACRL, 331

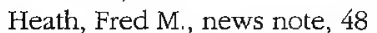

Hedberg, Jane, "Preservation news," 40, 45, 116, 200, 273, $340,411,476,551,622,677,759$

Higginbottom, Patricia C., news note, 48

"Higher education ICT initiative established," 647

Hillson, Barbara, rev. ("Population Reference Bureau"), 76061

"Historically Black Colleges formalize alliance," 237

"History," ACRL, 33, 109, 545

"HistoryCentral.com," rev. of, 343

Holler, Susan, news note, 768

Holley, Robert P., "The ivory tower as preparation for the trenches: the relationship between library education and library practice," 172-75

"Hoover Institution on War, Revolution, and Peace," rev. of, 625

Hopp, Ralph Harvey, deceased, 216

Horst, Victoria A., news note, 685

"Horticulture: sources for gardeners," Fescemyer, 312-15

"How successful is copy cataloging at catching and fixing typographical errors in records imported from bibliographic utilities?", Beall, 704

Howell, Elizabeth, "New relationships in academe: opportunities for vitality and relevance," 24-27

Hrabowski, Freeman A., photo., 509

Hugh C. Atkinson Memorial Award, 2003, 324; 2004, 541

Hughes, Jennifer, photo, 239

Hyde, Gene, rev. ("Virtually Missouri" \& logo), 42

\section{I}

"If you build it, will they come?: reaching out to faculty through information literacy instruction," Moore, 45557

"ILCSO welcomes 12 new members," 235

"In a Tropical Garden was created to promote the PanamaCalifornia Expedition held in San Diego in 1915," a postcard, 701 (photo., cover, no. 11)

"In the News", Orphan, 4, 74, 146, 234, 298, 366, 438, 502, $582,646,702$

"Index browsing available through EBSCOhost," 647

"ITW Library Skills Exchange," Mizzy, 709

"IAA to push for revised analysis of publisher mergers," 585
"Information Literacy Meeting of Experts drafts principles," 647

"Informationist," Mizzy, 177

"Informationists: making rounds makes a difference" \& ports., Mizzy, 176-77

"Ingenta adds three U.S. association publishers," 442

"Ingenta launches library usage statistics," 506

"Ingenta provides online solutions for World Bank, Oxford Univ. Press," 149

Ingles, Ernie, photo., 509

Innovation in Instruction Award, 2003, 327; 2004, 542

"Innovative offers digital collections solutions," 148

"Innovative offers electronic ordering for EBSCO books," 5 "Innovative to offer Linux option," 368

ISI, Doctoral Dissertation Fellowship, 2003, 262; 2004, 542; Samuel Lazerow Fellowship, 2004, 542; Samuel Lazerow Fellowship, 2003, 262

"ISI enhances Current Contents with eFirst," 235

"IEEE offers information technology library," 150

"IEEE to price online products lower than print," 649

"Institute of International Bankers donating copies of study to libraries," $585-86$

Instruction Section Publication of the Year Award, 2003, $325 ; 2004,542$

"Instruction Section to offer preconference in Toronto," 76, 237 "Instructional leadership: new responsibilities for a new reality," Fowler, 456-68, 465-68, correction, 546

"Integrating information literacy into the learning outcomes of academic disciplines: a critical 21st-century issue," Rockman, 612-15

"Integrating outreach and building partnerships: expanding our role in the learning community," Cawthorne, 66669, 681

Internet resources ("Archives and special collections: a guide to resources on the Web" \& logos, Zanish-Belcher, 163-66; "Criminal investigation and forensic science: sources for scholars and aficionados" \& logos, Alpi, 59093, 609; "Culinary tesources: cookery and culinary history Web sites" \& logos, Summerfield, 656-59; "E-poetry: digital frontiers for an evolving art form" \& logos, Shirkey, 249-51; "Educational technology: a guide to resources on the Web" \& logos, Batemen, 9-12; "Horticulture: sources for gardeners," Fescemyer, 312-15; "Latin America on the Intemet: a bibliography" \& logos, Tarragó, 710-12; "More about Southeast Asia," Klopfer, 106; "More on archives and special collections," ZanishBelcher, 166; "Nonprint media preservation: a guide to resources on the Web" \& logos, Pennavaria, 529-32 "Photojoumalism on the Web: a guide for practicing and student photojournalists" \& logos, Cammarata, 451-54; "Plagiarism and cyber-plagiarism: a guide to selected resources on the Web" \& logos, Simmonds, 385-89; "Southeast Asian studies: online resources" \& logos, Klopfer, 96-99, 106)

"Internet reviews," Roberts, 42-43, 118-19, 202-3, 274-75, $342-43,413-14,477-78,552-53,624-25,678-79,760$ 61

Iris \& B. Gerald Cantor Art Gallery, Leab Award, 325

"It's coming! New ACRL Web site to launch in April," 148 "It's not just academic (1) your library," 6

"It's not just academic @ your library: the Campaign for America's Libraries Academic and Research Library Campaign" \& photo., Spalding, 159-60

"The ivory tower as preparation for the trenches: the relationship between library education and library practice," Holley, 172-75

\section{$\mathbf{J}$}

Jacobson, Gertrude "Trudy," deceased, 688

Jahoda, Gerald, deceased, 688

Jerome, Rebecca, port., 176

"Jetome Rollers, a newly formed library drill team, performing in the Bowling Green State University Holiday Parade" photo., 14, correction, 77 
Job of a lifetime ("Adventure, mystery, romance, and LCSH!" \& photos., Mizzy, 14-15, correction, 77; "Bringing history to life" \& port., Mizzy, 596-97; "Digital projects manager," Mizzy, 597; "ITW Library Skills Exchange," Mizzy, 709; "Informationist," Mizzy, 177; "Informationists: making rounds makes a difference" \& ports., Mizzy, 176-77; "Observations of an observatory librarian" \& port., Mizzy, 458-59; "Off-campus librarian," Mizzy, 317; "Popular culture cataloger and reference librarian," Mizzy, 15; "Solo librarian," Mizzy, 459; "When your campus is Alaska" \& port., Mizzy, 316-17; "World Library Partnership" \& photo., Mizzy, 708-9)

"Johns Hopkins restores water-damaged books," 504-5

Johnson, Wendell, rev. ("Legends" \& logo), 202

"Join WESS in Paris in March 2004," 584

Jones, Rita, photos., 518, 520, 745

Joseph, Heather, "Two years after the launch: an update on the BioOne electronic publishing initiative," $652-55$

JSTOR, "WilsonWeb databases now link to JSTOR," 585

"ISTOR reports unauthorized use through open proxies," 57

\section{$\mathbf{K}$}

K. G. Saur Award for Best CERL Article, 2003, 326

Kan. State U., "Using an executive search firm to fill faculty library positions: one library's story," 523-25

Kastanis, Penny, news note, 279

Katharine Kyes Leab and Daniel J. Leab American Book Prices Current Exhibition Catalogue Awards, 2003, 325$26 ; 2004,542$

Keillor, Garrison, photo., 706

Keller, Jan, retired, 349

Keller, Michael, news note, 279

Kellsey, Charlene, "Crisis in foreign language expertise in rescarch Iibraries: how do we fill this gap?", 391-92, 397

"Kenan Research Center opens at Atlanta History Center," 77

Keyse, Dana, "Mentoring untenured librarians: all it takes is a little Un-TLC," 378-80

Kirk, Tom, photo., 512

Klavans, Judith $\mathrm{L}$., news note, 560

Klopfer, Lisa, "More about Southeast Asia," 106; "Southeast Asian studies: online resources" \& logos, 96-99, 106

Koller, Nancy, retired \& port., 633-34

Koonce, Taneya, port., 176

Koren, Johan, appt., 214

Kosokoff, Jeff, photo., 441

Kraemer, Elizabeth W., "Mentoring untenured librarians: all it takes is a little Un-TLC," 378-80

Kratz, Charles, "Transforming the delivery of service: the joint-use library and information commons," 100-101

Kreitz, Patricia A., photos., 518, 520

Kreitz, Patricia K, photo., 745

Krempasky, Fran, news note, 348

Krolikowski, Cindy, news note, 348

Kuchi, Triveni, rev. ("Social Science Information Gateway (SOSIG)" \& logo), 477-78

\section{$\mathbf{L}$}

LaBash, Steve, appt., 348

The Lady of the Lilies (c. 1910) by Kathy Prather Thum, 365 (photo., cover, no. 6)

Lampert, Lynn D., "Who's afraid of partnerships for information literacy initiatives? Working together to empower learners," 246-48, 253

Lange (Marta)/CQ Award, 2003, 263; 2004, 541-42

"Latin America on the Internet: a bibliography" \& logos, Tarragó, 710-12

"Lazerow Fellowship recipients research copy cataloging and electronic resources management systems," 704-5

Lazerow (Samuel) Fellowship, 2004,542

Lazerow (Samuel) Fellowship, 2003, 262

"Leab Exhibition Award winners named," 325-26
Leab (Katharine Kyes and Daniel J.) American Book Prices Current Exhibition Catalogue Awards, 2003, 325-26; 2004, 542

"The LEADER project: becoming an information LEADER at Purdue University," Macklin, 192-95

"The learning community as knowledge builders: the 200304 ACRL President's theme," Cannon, 533-35

"Learning to make a difference: Charlotte, North Carolina, April 10-13: preliminary program" \& photos., ACRL, National Conference, 2003, C-1—C-28 (no.1)

"Learning to make a difference: coverage from ACRL's 11th National Conference, part 1" \& photos. \& ports., 372 377, 409; part 2" \& photos., 443-88, 454

"Learning to Make a Difference: Proceedings of the ACRL 11 th National Conference is available," 401

Lee, Catherine A., news notes, 685, 768

lee, Chang C., retired \& port., 634

"The legend of the roasted tanner," 194

"Legends" \& logo, rev. of, 202

Lehman, Charlene, retired, 50

Lehner, John, "News from the University Libraries Section: a wrap-up of activities at Midwinter," 254-55

Leonhardt, Thomas W., appt., 214

Leopold, Alan, photo., 211

Lewis, Janice Steed, "Eight steps for developing a first-year English composition award: a look at a successful program at East Carolina University" \& photo., 238-40

"LexisNexis provides free information on war in Iraq," 300

"LexisNexis to create digital U.S. Congressional Serial Set," 585

Lib. of Va., Leab Award, 325

Linke, Erika C., "Financial report" \& port., 746-50; photos., 518,745

"Literature, Arts, and Medicine Database," rev. of, 43

Little, Rosemary Allen, "Honored with Marta Lange/CQ award, " 263

Lokke, Margaret Jean, deceased, 485

Long Island U., "Palmer School developing rare books program," 76

Lougee, Wendy Pradt, photo., 706; "This year's Atkinson winner announced" \& port., 324

Lougen, Colleen, rev. ("globalEDGE" \& logo), 624-25

Loyola U., New Orleans, "Excellence in Academic Libraries winners announced," 260, 262

Lubetzky, Seymour, deceased, 485

Lyman, Helen $\mathrm{H}$., deceased, 50

McCallister, Myrna, appt., 279

McCulley, Carol, rev. ("Center for Biologics Evaluation and Research" \& logo), 552

MacDonald, Mary C., rev. ("Civilrights.org: the Progressive Coalition for Equal Opportunity" \& logo), 119

McKinnell, Jennifer, rev. ("Nutrition.gov" \& logo), 342-43

Macklin, Alexius Smith, "The LEADER project: becoming an information LEADER at Purdue University," 192-95

McMillan, Gail, news note, 420

McTigue, Bernard, deceased \& port., 634

"Maine libraries choose Endeavor's Encompass," 236

"Malcolm X papers placed on deposit at NYPL's Schomburg Center," 77

Malenfant, Kara, photo., 708

Maloy, Frances, ACRL, vice-president \& port., 398-400; ports., $28-29,102,104-6$

"Marcel Dekker launches e-book sites," 703

Marcum, Deanna, appt., 560

Marcus, Sandra, "Multilingualism at the reference desk: keeping students connected," 322-23, 336

"Marquette dedicates new library" \& port., 649

Marshall, Joan K., deceased, 562

Marta Lange/CQ Award, 2003, 263; 2004, 541-42

Martin, Susan K., photo., 446; port., 754

"The Martin Luther King Jr. Papers Project," rev. of, 760

Masnik, Ann, news note \& port., 482 
"Massachusetts Center for the Book celebrates books, reading, and libraries," 235

MIT, "DSpace Federation collaboration announced," 147

"MIT and Rice Univ. join Digital Library Federation," 506

"MIT launches DSpace," 5

Matthews, Linda, appt. \& port., 631

Maymi-Sugrañes, Hector, appt, 685

"Mediafinder provides online subscription reference for periodicals," 7 ?

"Meet Alire and Kratz — candidates for ACRL President," 718

"Meet the ACRL Board," 38

"Meet the ACRL staff," 752-55

"Meet the candidates for ALA president: vote in the election this spring" \& ports., 182-88

"Members-only content now available on ACRL Web site," 504

"Members running for ALA Council," ACRL, 190

Membership Services at the Chicago Multitype Lib. System, "World Library Partnership" \& photo., 708-9, 709

"Mentoring untenured librarians: all it takes is a little UnTLC," Keyse, 378-80

Middleton, Vanessa, news note, 348

Miller, John, deceased \& port., 280

Miller, Lisa K., rev. ("World Resources Institute"), 42-43

Miller, Rush, news note, 48

Miriam Dudley Instruction Librarian Award, 2003, 262-63; 2004,542

Mitchell, W. Bede, photos., 518, 520, 745

Mizzy, Danianne, "Adventure, mystery, romance, and LCSH!" \& photos., 14-15, correction, 77; "Bringing history to life" \& port., 596-97; "Digital projects manager," 597; "ITW Library Skills Exchange," 709; "Informationist," 177; "Informationists: making rounds makes a difference" \& ports., 176-77; "Observations of an observatory librarian" \& port., 458-59; "Off-campus librarian," 317; "Popular culture cataloger and reference librarian," 15; "Solo librarian," 459; "When your campus is Alaska" \& port., 316-17; "World Library Partnership" \& photo., 708-9

"Monticello: the Home of Thomas Jefferson" \& logo, rev. of, 761

Moore, Lara J., deceased \& port., 562

Moore, Melissa, "If you build it, will they come?: reaching out to faculty through information literacy instruction," 455-57

"More about Southeast Asia," Klopfer, 106

"More on archives and special collections," Zanish-Belcher, 166

Morrissett, Elizabeth Ellen Winkelmann, deceased, 634

Mueller, Dawn, port., 754

"Multilingualism at the reference desk: keeping students connected, " Marcus, 322-23, 336

"Multimedia Educational Resource for Learning and Online Teaching (MERLOT)" \& logo, rev. of, 413

Murray-Rust, Catherine, appt. \& port., 631-32

"Music literature abstracts available through IDS," 302

\section{$\mathbf{N}$}

NARA, "GPO and NARA support permanent online access," 583

"National Center for Health Statistics" \& logo, rev. of, 118

"National Partnership for Women \& Families" \& logo, rev. of, 342

"NationMaster.com" \& logo, rev. of, 678

Nauta, Tjalda, appt. \& port., 124

"Navigating a tight job market: there's a job for you," Saunders, 661-63, 669

Neal, James, photo., 446

Neal, James G., "Reaction to terror: gauging the aftermath and the impact of USA PATRIOT legislation," 78-79

"New publications," Eberhart, 44-45 (\& photos.), 120-21 (\& photo.), 206-8 (\& photo.), 277 (\& photo.), 344-45 (\& photo.), 416-17 (\& photo.), 479-80 (\& photos.), 554555 (\& photo.), 626-27 (\& photos.), 680-81 (\& photos.), 762-64 (\& photos.); Parets, guest reviewer, 344
New realities, new relationships ("Diversity initiatives $v s$. residency programs: agents of change?, Hankins, 30810, 315; "Got a secret? Pass it on ...: recruiting new librarians," Chmelir, 395-97; "The ivory tower as preparation for the trenches: the relationship between library education and library practice," Holley, 172-75; "New relationships in academe: opportunities for vitality and relevance," Frank, 24-27; "Recruiting for librarianship," Chmelir, 396; "Transforming the delivery of service: the joint-use library and information commons," Kratz, 100-101; "Who's afraid of partnerships for information literacy initiatives? Working together to empower learners," Lampert, 246-48, 253)

"New realities, new relationships," ACRL, Annual report, 2002-2003, 725

"New relationships in academe: opportunities for vitality and relevance," Frank, 24-27

NYPL, Leab Award, 325; "Malcolm X papers placed on deposit at NYPL's Schomburg Center," 77; "Russia Engages the World, 1435-1825," a major exhibition at the New York Public Library, 645 (photo., cover, no. 10)

"NYPL launches emergency campaign," 367

"NYPL Picture Collection goes digital," 147

"NYU kicks off library renovation," 75

Newlen, Robert R., "Meet the candidates for ALA president: vote in the election this spring" \& port., 182-88

"News from the field," Orphan, 5-7, 75-77, 147-50, 235-37, 299-302, 367-70, 439-42, 503-6, 583-86, 647-50, 7036

"News from the University Libraries Section: a wrap-up of activities at Midwinter," Sherby, 254-55

Newton, Verne W., appt., 632

Nilsson, Frances Stith, news note, 123

Nisbet, Miriam, "Washington hotline," 38

Nitschke, Marie Morris, retired, 687-88

"Nonprint media preservation: a guide to resources on the Web" \& logos, Pennavaria, 529-32

Norstedt, Marilyn L., deceased \& port., 562

"Nunez Community College participating in digital library," 5 "Nutrition gov" \& logo, rev. of, 342-43

Nutty, David J., appt., 685

o

Oakland U., "Mentoring untenured librarians: all it takes is a little Un-TLC," 378-80

Oberly (Eunice Rockwell) Award, 2003, 326

"Observations of an observatory librarian" \& port., Mizzy, 458-59

"OCLC pricing to remain unchanged in 2004," 439

"Off-campus librarian," Mizzy, 317

Ohio State U., "DSpace Federation collaboration announced," 147

"OhioLink celebrates ten years," 7

"OhioLINK updates catalog, introduces pick-up feature," 586

"Old Dominion celebrates 40 years as a federal depository," 648

Olson, Michael P., "Wins Coutts Nijhoff Study Grant," 326-27

"Omniglot: a guide to writing systems" \& logo, rev. of, 678-79

"Open-access PLoS journal receives kudos," 648-49

Orenstein, David, appt., 560

Orphan, Stephanie, "In the News", 4, 74, 146, 234, 298, $366,438,502,582,646,702$; "News from the field," 5 7, 75-77, 147-50, 235-37, 299-302, 367-70, 439-42, 503-6, 583-86, 647-50, 703-6; port., 754

Osterloh, Cassandra E., rev. ("A Celebration of Women Writers" \& logo), 202-3; rev. ("Omniglot: a guide to writing systems" \& logo), 678-79

Outstanding Academic Titles, "CHOICE offers compilation of Outstanding Academic Titles", 505

$\mathbf{P}$

Padley, Pamela Moffett, "The President's Discussion Forum at Midwinter: exploring a world of values," 252-53 
"Palmer School developing rare books program," 76

"Pan American Unity," two panels from the mural, Rivera, 501 (photo., cover, no. 8)

"Panel session," ACRL, 111

Pankake, Marcia, photo., 706

Parets, Meredith, "New publications," guest reviewer, 344 Parker, Elise, port., 755

"Participate in the ACRL strategic planning process," 505

Partnerships and connections ("The community college library perspective in an age of opportunity: meeting expectations in times of uncertainty," Fradkin, 721-23; "Integrating outreach and building partnerships: expanding our role in the learning community," Cawthorne, 666-69, 681; "The learning community as knowledge builders: the 2003-04 ACRL President's theme, "Cannon, 533-35)

"The PATRIOT Act and higher education," 717

Pattillo, Gary, "Fast facts," 578, 642, 698, 790

Paulson, Keri-Lynn, "Recruitment, education, and retention of librarians: a response to the top issues," 89

Peach, Janis K., "Assessment of reference instruction as a teaching and learning activity: an experiment at the University of Illinois-Springfield," 256-58

Pennavaria, Katherine, "Nonprint media preservation: a guide to resources on the Web" \& logos, 529-32

"Pennsylvania libraries choose Docutek," 369-70

"People in the News", Galloway, 48-50, 123-25, 214-16, $279-80,348-49,420-21,482-85,560-62,631-34,685-$ $88,768-71$

Perry, Gerald J., news note, 48

Person, Roland, retired, 561

Peterson, Betty Jo, deceased, 125

Petrowski, Mary Jane, 'ACRL's 2004 awards program: honoring outstanding achievements in academic librarianship" \& photo., 541-42; port., 755

"The Pew Research Center for the People and the Press" \& logo, rev. of, 275

Philadelphia U., "Stop sending those cards: enhancing facultylibrarian collaboration using e-selection strategies, "6069

Phillips, Jane, photo., 504

"Photojournalism on the Web: a guide for practicing and student photojournalists" \& logos, Cammarata, 451-54

Piatz, Carolyn, rev. ("St. Nicholas: Discovering the Truth about Santa Claus" \& logo), 679

Pickett, Doyle C., deceased, 562

Pickthall, Marjorie, "The cover illustration is from the Marjorie Pickthall Manuscript Collections in the Special Collections of the Victoria University at the University of Toronto's E. J. Pratt Library," 297 (photo., cover, no.5)

Pierpont Morgan Lib., Leab Award honorable mention, 32526

"Piracy on campuses: opportunity not problem," Ferullo, 664-65

Pitchford, Veronda, photo., 708

"Plagiarism and cyber-plagiarism: a guide to selected resources on the Web" \& logos, Simmonds, 385-89

Popko, John, photo., 510

"Popular culture cataloger and reference librarian," Mizzy, 15

"Population Reference Bureau," rev. of, 760-61

"Poynteronline" \& logo, rev. of, 553

"Preservation news," Hedberg, 40, 45, 116, 200, 273, 340, $411,476,551,622,677,759$

"The President's Discussion Forum at Midwinter: exploring a world of values," Padley, 252-53

"Principles and strategies for the reform of scholarly communication: issues related to the formal system of scholarly communication," ACRL, 526-27, 547

Pritchard, Sarah, news note, 279

"Proceedings available," 377

"Project Muse offers flex-plan," 506

"ProQuest enters into linking partnerships," 148

"Proquest offers electronic dissertation submission program," 75
Puckett, Anita, news note, 420

Purdue U., "The LEADER project: becoming an information LEADER at Purdue University," 192-95

Putin, Vladimir, "Tours Columbia U. archive," 649-50

Q

Quinlan, Catherine, news note, 123

$\mathbf{R}$

Rappaport, Ellen Coolman, deceased, 562

Ratliff, Ron, "Using an executive search firm to fill faculty library positions: one library's story," 523-25

Raynor, Ginger, photo., 239

"Reaction to terror: gauging the aftermath and the impact of USA PATRIOT legislation," Neal, 78-79

"Read the expanded article," Suber, 94, correction, 149

"Readers' Guide online via WilsonWeb," 76

Reakes, Patrick, rev. ("Poynteronline" \& logo), 553

"Records of Iraqi civilization destroyed," Sharma, 368-69

"Recruiting for librarianship," Chmelir, 396

"Recruitment, education, and retention of librarians: a response to the top issues, "Paulson, 89

Reeser, Gale, retired, 421

"Reference Universe supports OpenURL protocol," 703

"Register now for 'Information Literacy and Assessment' online seminar," 457

"Register now for the ACRL/Harvard Leadership Institute August 3-8, 2003, Cambridge, Massachusetts," 302, 370

"Removing barriers to research: an introduction to open access for librarians, "Suber, 92-94, 113, correction, 149

Renfrow, Debbie, rev. ("American Folkdife Center: the Library of Congress" \& logo), 624

Répertoire International de Littérature Musicale (RILM), "Music literature abstracts available through IDS," 302

Repplinger, John, rev. ("Agriculture Network Information Center "\& logo), 203

"Research agenda for library instruction and information literacy," ACRL, updated version, 108-13

Retirements, $50,125,216,280,349,421,484-85,561$, $633-34,687-88$

"Revising the guidelines," ACRL, 266-67

Rice U., "MIT and Rice Univ. join Digital Library Federation," 506

Richardson, John V., news note \& port, 214

Rivera, Diego, "Pan American Unity," two panels from the mural, 501 (photo., cover, no. 8)

Robare, Lori, rev. ("Literature, Arts, and Medicine Database"), 43

Roberts, Joni R, "Internet reviews," $42-43,118-19,202-3$, $274-75,342-43,413-14,477-78,552-53,624-25,678-$ $79,760-61$

Rockman, Ilene, "Named EBSS Distinguished Librarian," 326 , correction, 468

Rockman, Ilene F., "Integrating information literacy into the learning outcomes of academic disciplines: a critical 21 st-century issue," 612-15

Rockwood, Irving, port., 755

Rose, Robert F., photo., 518, 745

Routledge Press, Significant Achievement in Women's Studies Librarianship, 2003, 263; 2004, 542

Ruelle, Joan D., appt., 420

Ruhl, Taylor, appt. \& port., 686

Russell, Thyra K., retired, 561

"Russia Engages the World, 1435-1825," a major exhibition at the New York Public Library, 645 (photo., cover, no. 10)

Rutgers U., "The bewildering new world of scholarly communication: helping faculty understand the issues," 242-245

s

St. Clair, Ann, appt., 632

St. Clair, Gloriana, appt. \& port., 632 
"St. Nicholas: Discovering the Truth about Santa Claus" \& logo, rev. of, 679

Samuel Lazerow Fellowship, 2004, 542

Samuel Lazerow Fellowship, 2003, 262

San Diego State U., "In a Tropical Garden was created to promote the Panama-Califomia Expedition held in San Diego in 1915," a postcard, 701 (photo., cover, no. 11); "Integrating outreach and building partnerships: expanding our role in the learning community," 666-69, 681

San Jose State U., "First joint city/university library opens its doors," 503

Saunders, Laura, "Navigating a tight job market: there's a job for you," 661-63, 669

Saunders, Laverna M., appt., 48

Saunders, Michele, "Diversity initiatives vs. residency programs: agents of change?, 308-10, 315

Saur (K. G.) Award for Best CERL Article, 2003, 326

Saye, Jerry, news note, 123

Schacht, John, retired, 688

Scherdin, Mary Jane, news note \& port., 48

Schmidt, Ford, rev. ("Monticello: the Home of Thomas Jefferson" \& logo), 761

Schmidt, Sherrie, news note, 48

Scholarly communication ("The bewildering new world of scholarly communication: helping faculty understand the issues," Dess, 242-245; "Principles and strategies for the reform of scholarly communication: issues related to the formal system of scholarly communication," ACRL, 526-27, 547; "Read the expanded article," Suber, 94, correction, 149; "Removing barriers to research: an introduction to open access for librarians," Suber, $92-$ 94, 113, correction, 149; "Two years after the launch: an update on the BioOne electronic publishing initiative," Joseph, 652-55; "Widespread academic efforts address the scholarly communication crisis: the results of a survey of academic institutions, Ward, 382-83, 389)

"SPARC announces Open Access Neusletter", 503

Schultz, Jason M., rev. ("Africa Action" \& logo), 478

Schumacher, Julie, photo., 706

"ScienceDirect offers Encyclopedia of Social \& Bebavioral Sciences online," 76-77

"Section committee volunteer form," ACRL, 603

Seidman, Ruth K, retired, 484

Senior, Heidi E. K., rev. ("Center for Applied Linguistics"), $274-75$

"Serials Solutions to freeze pricing schedule," 583

Service, Rose Marie, deceased, 50

Shane, Jordana, "Stop sending those cards: enhancing facultylibrarian collaboration using e-selection strategies," 6069

"Share your effective practices through ACRL's clearinghouse," 703

"Share your ideas with the ACRL Board," 716

"Share your library's effective practices through ACRL clearinghouse," 150

Shama, R. N. "Records of Iraqi civilization destroyed," 368-69

Sheen, Martin, photo., 649

Sherby, Iouise S., "News from the University Libraries Section: a wrap-up of activities at Midwinter," 254-55

Sherrod, Stephanie, "ACRL honors the 2003 award winners: a recognition of professional achievement," 260-63; "ACRL honors the 2003 award winners: the final installment of ACRL award winners," 324-27

Shirkey, Cynthia D., "E-poetry: digital frontiers for an evolving art form" \& logos, 249-51

Shupert, Cheryl, cartoon, 5

Sibley, Deborah, appt., 483

Sickles, Bob, retired, 634

Significant Achievement in Women's Studies Librarianship, 2003,$263 ; 2004,542$

Simmonds, Patience, "Plagiarism and cyber-plagiarism: a guide to selected resources on the Web" \& logos, 385-89

Simmons, Kitty J., appt., 279
Simmons Coll., "Massachusetts Center for the Book celebrates books, reading, and libraries," 235

Simmons-Welburn, Janice, appt., 632

Simpson, Charles, appt., 483

Sims, Arlie, photo, 708

Singleton, Brett, "Entering academic librarianship: tips for library school students," 84-86, correction, 245

"Sirsi selected by Bibliocentre," 301

Situ, Ping, "Diversity initiatives $v s$, residency programs: agents of change?, 308-10, 315

Smith, Mark A., rev. ("Multimedia Educational Resource for Learning and Online Teaching (MERLOT)" \& logo), 413

"Smithsonian opens natural history library," 148

Snavely, Loanne, "Wins IS Miriam Dudley Instruction Librarian Anvard" \& port., 262-63

Snelson, Pamela, photos., 518, 520,745

"Social Science Information Gateway (SOSIG)" \& logo, rev. of, $477-78$

"Solo librarian," Mizzy, 459

"Southeast Asian studies: online resources" \& logos, Klopfer, 96-99, 106

Spalding, Helen H.. "It's not just academic @ your library: the Campaign for America's Libraries Academic and Research Library Campaign" \& photo., 159-60; "Message from the president" \& port., 726-27; photos., 372, 377, $444,504,509,514,518,520,541,745$

Sparrow, W. Keats, photo., 239

"Spine-health.com" \& logo, rev of, 413-14́

"Standards for libraries in higher education," ACRL, a draft, 329-36

Stanford U., Leab Award honorable mention, 325

SUNY, Plattsburgh, "Those immersed resurface: a follow up with Track 2 participants of the first Information Literacy Immersion," 17-19

Steele, Pat, news note \& port., 482

Stetson U., "A detail from an illustration in the multivolume work Description de L'Égypte, ou Recueil des Observations...", 73 (photo., cover, no. 2)

Stewart, Sharon, retired, 50

Stockham, Marcia, "Using an executive search firm to fill faculty library positions: one library's story," 523-25

Stoffan, Mark A., rev. ("HistoryCentral.com"), 343

Stokes, Allen H., retired, 484

"Stop sending those cards: enhancing faculty-librarian collaboration using e-selection strategies," Shane, 606-9

"Strategies to keep the wolf from the door: collection development when the budget is tight," Dillon, 536-37

"A street corner in San Francisco's China Town, circa 1890," Blum, 437 (photo., cover, no. 7)

Strong, Gary E., appt., 420

Suber, Peter, "Read the expanded article," 94, correction, 149; "Removing barriers to research: an introduction to open access for librarians," 92-94, 113, correction, 149

"Subscribe to ACRL e-mail updates," 336

Summerfield, Susan, "Culinary resources: cookery and culinary history Web sites" \& logos, 656-59

"Swets Blackwell to change name," 584

Swords, David, photo., 514

Tacchi, Mary Jane, deceased, 771

"Take a ride on this charming trolley when you visit Charlotte, North Carolina," ACRL, National Conference, 2003, 3 (photo., cover, no. 1)

"Taking immersion home: applying lessons learned at ACRL's Immersion Program," "Garrett, 587-88, 609

Tarragó, Rafael, "Latin America on the Intemet: a bibliography" \& logos, $710-12$

Taylor, Tomaro, appt. \& port., 483

Tex. A\&M U., "Diversity initiatives vs, residency programs: agents of change?, 308-10, 315

Tex. Tech U., "Turkish archive available through Texas Tech," $149-50$ 
"There's money out there for you: writing personal grants," Burke, 155-57, 170

Thomas, Sarah, news note, $768-69$

Thompson, Hugh, port., 755

Thompson, Laurie L., appt., 420

"Those immersed resurface: a follow up with Track 2 participants of the first Information Literacy Immersion," Toth, 17-19

Thum, Kathy Prather, The Lady of the Lilies (c. 1910) by Kathy Prather Thum, 365 (photo., cover, no. 6)

Tiemey, Barbara, “The Carolinas' rich library legacy: touring Charlotte-area libraries at the ACRL National Conference" \& photos., 80-83; "Charlotte nights: what to do at the end of the conference day" \& photos., 179-181; "Charloue on the Web," 180; "Transportation information," 181

Tonner, Shawn, appt., 560

Toth, Michelle, "Those immersed resurface: a follow up with Track 2 participants of the first Information Literacy Immersion," 17-19

Totten, Herman L., "Meet the candidates for ALA president: vote in the election this spring" \& port., 182-88

Toyama, Ryoko, retired \& port., 484-85

"Transforming the delivery of service: the joint-use library and information commons," Kratz, 100-101

"Transportation information," Tierney, 181

Trinity Coll., "CTW Library Consortium chooses Voyager," 439

Troutman, Leslie, deceased \& port., 485

Truitt, Marc, "Farrell \& Truitt awarded Lazerow Fellowship," 262; photo., 541, correction, 585

Tryka, Kim, port., 596

"Turkish archive available through Texas Tech," 149-50

Turkos, Anne, news note \& port., 769

"Twenty-four early career librarians participated in the University of Minnesota's biennial training for librarians from underrepresented groups" photo., 7

"2003 ALA Annual Conference audiotapes now available," 511

"2003-04 ACRL chapter conferences/events," 604-5

"Two years after the launch: an update on the BioOne electronic publishing initiative," Joseph, 652-55

$\mathbf{U}$

Union Theological Serninary, "Burke Library to join Columbia," 302

Union U., "If you build it, will they come?: reaching out to faculty through information literacy instruction," 45557

"U.S. Institute of Peace" \& logo, rev. of, 414

U. of Alaska, Fairbanks, "Off-campus librarian," 317; "When your campus is Alaska" \& port., 316-17

U. of Ariz., "Observations of an observatory librarian" \& port., 458-59; "Solo librarian," 459

UC, Berkeley, "Archives and special collections: $24 / 7$," 440; Leab Award Special Commendation for Electronic Exhibitions, 326; "A street corner in San Francisco's China Town, circa 1890," 437 (photo., cover, no. 7)

"UC Irvine dedicates library," 703

"UCLA selects Endeavor," 703, 706

U. of Del., "Diversity initiatives vs. residency programs: agents of change?, 308-10, 315

U. of Ill., Chicago, "Blue Lady" was designed for the cover of the Stone and Kimball publication The Chap-Book, Bradley, 581 (photo., cover, no. 9)

U. of Ill., Springfield, "Assessment of reference instruction as a teaching and learning activity: an experiment at the University of Illinois-Springfield," 256-58

"Univ. of Maryland to offer Master of Information Management degree, ${ }^{n} 235-36$

U. of Mich., "Wins IS Innovation in Instruction Award," 327

"U. of Minnesota holds biennial training for librarians from underrepresented groups" \& photo., 7
"UNC-Chapel Hill graduates first class of IS undergrads," 439

"UNC-Chapel Hill undergraduate library reopens," 5

"UNC Charlotte joins ASERL's Kudzu project," 150

U. of Or., "Getting to know your subject specialty: add a little romance (literature) to your life," 318-20

"Univ. of Pittsburgh launches eprint archive," 301

$\mathrm{U}$. of Rochester, "DSpace Federation collaboration announced," 147

"USF libraries help Addis Ababa University Library," 583

U. of Tenn., "Taking immersion home: applying lessons learned at ACRL's Immersion Program," 587-88, 609

U. of Toronto, "The cover illustration is from the Marjorie Pickthall Manuscript Collections in the Special Collections of the Victoria University at the University of Toronto's E. J. Pratt Library," 297 (photo., cover, no.5); "DSpace Federation collaboration announced," 147

U. of Va., "Bringing history to life" \& port., 596-97; "Digital projects manager," 597

U. of Wash., "DSpace Federation collaboration announced," 147

"UIUC moves the Newspaper Library to remodeled location," 369

"UTUC adds one-of-a-kind book as 10 millionth volume," 649

"University of Louisville to launch library expansion," 367

"UTA libraries feature Tejano voices," 148-49

Unsworth, John M., appt., 348

"Using an executive search firm to fill faculty library positions: one library's story," Stockham, 523-25

$\mathbf{v}$

Valentine, Barbara, rev. (The Pew Research Center for the People and the Press" \& logo), 275

Van Norman, Clare, photo., 419

Van Ornum, Mary, "Without a cross word: one library's answer to torn out text" \& a crossword, 460-61

Vandebilt U., "Informationist," 177 ; "Informationists: making rounds makes a difference" \& ports., 176-77

Vann, J. Daniel, appt. \& port., 632

Varner, Carroll, photo., 239

Vassar Coll., "Without a cross word: one library's answer to torn out text" \& a crossword, 460-61

Victoria U., "The cover illustration is from the Marjorie Pickthall Manuscript Collections in the Special Collections of the Victoria University at the University of Toronto's E. J Pratt Library," 297 (photo., cover, no.5)

Viles, Ann, "Fast facts," 70, 138, 230, 294, 362, 434, 498; "Steps down as 'Fast Facts' editor," 441

"Virtually Missouri" \& logo, rev. of, 42

Voelck, Julie, "Mentoring untenured librarians: all it takes is a little Un-TLC," 378-80

\section{$\mathbf{W}$}

Walker, William D., appt. \& port., 632

Walter, Scott, "Instructional leadership: new responsibilities for a new reality," 465-68

Walton, Linda J., news note, 48

Wand, Pat, news note, 483

Wand, Patricia A., photos., 518, 520, 745

Ward, Heather E., "Getting to know your subject specialty: add a little romance (literature) to your life," 318-20

Ward, Randall, "Widespread academic efforts address the scholarly communication crisis: the results of a survey of academic institutions, 382-83, 389

"Washington hotline," Bradley, 198, 272, 338, 409, 475, 549, 620, 674, 756-57, 771; Nisbet, 38; Weingarten, 114

Watson-Boone, Peter, retired \& port., 688

Waugh, Kappa, cartoons, 75, 147, 235, 299, 367, 439, 503, $583,647,703$

Wawrzaszek, Susan V., appt., 560

The way I see it ("Diversity: it's not just the right thing to do," Goss, 594-95, 605; "Multilingualism at the reference 
desk: keeping students connected," Marcus, 322-23, 336; "Piracy on campuses: opportunity not problem," Ferullo, 664-65)

"Webcasts of ACRL National Conference programs available," 299

Weingarten, Rick, "Washington hotline," 114

Weiss, Egon, deceased, 771

Weiss, Gerhard, photo., 706

Wesleyan U., "CTW Library Consortium chooses Voyager," 439

W. Ken. U., The Lady of the Lilies (c. 1910) by Kathy Prather Thum, 365 (photo., cover, no. 6)

Wheelan, Bell, photo., 377

"When the library becomes the largest computer lab on campus: supporting productivity software in an academic environment," Graham, 462-64, 468

"When your campus is Alaska" \& port., Mizzy, 316-17

White, Herbert S., news note, 483

"Who's afraid of partnerships for information literacy initiatives? Working together to empower learners," Lampert, 246-48, 253

"Widespread academic efforts address the scholarly communication crisis: the results of a survey of academic institutions, Ward, 382-83, 389

Wildemuth, Barbara, news note, 124
Williams, Sylvia Murphy, deceased, 421

Willis, Paul, news note, 48

Wilson, Myoung C., "The bewildering new world of scholarly communication: helping faculty understand the issues," $242-245$

"WilsonWeb databases now link to JSTOR," 585

"WilsonWeb expands art and social sciences database," 299

Windsor, Elizabeth A., deceased, 688

Windsor, Elizabeth Arnold, deceased \& port., 421

"Without a cross word: one library's answer to torn out text" \& a crossword, Van Ornum, 460-61

Wolfe, N. J., appt. \& port., 279

"World Library Partnership" \& photo., Mizzy, 708-9

"World Resources Institute," rev. of, 42-43

$\mathbf{Y}$

Yale U., "Symposium designed to recruit librarians," 439, 441

YBP Library Services, "Dynix and YBP Library Services enter partnership," 302

$\mathbf{Z}$

Zanish-Belcher, Tanya, "Archives and special collections: a guide to resources on the Web" \& logos, 163-66; "More on archives and special collections," 166

\section{Make NO Mistake}

According to a recent readership survey of librarians and higher education faculty:

- $79 \%$ of subscribers polled rely on CHOICE reviews to make their material selections!

- $51 \%$ use CHOICE reviews as their primary collection development tool!

- Compared to 10 other leading review sources, CHOICE reviews were preferred by 5 to 1 !

- For the best, short critical evaluations of new titles anywhere, readers favored CHOICE 8 to 1 !

If you purchase material for your college library collection and are looking for exciting new ways to make selecting books and Internet resources easier, faster, and more efficient than ever...

There Is Only One CHOICE!

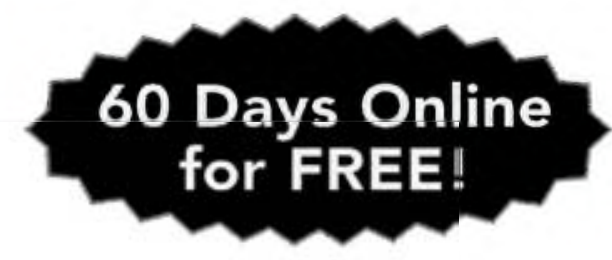

To try ChoiceReviews.online or our NEW ChoiceReviews.on ine Site License Edition FREE for $\mathbf{6 0}$ days, click on www. ChoiceReviews.org. To subscribe to $\mathrm{CHOICE}$ Magazine or Reviews On Cards, contact us at www.ala.org/acrl/choice, or call (240) 646-7027.

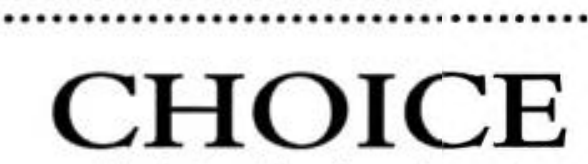

The internationally-accleimed source of current reviews for academic libraries.

CHOICE is a publication of the Association of College \& Research Libraries, a Division of the American Library Association. 


\section{Many great inventions originated in China. Starting right here. 1}

From gunpowder to space flight, China's remarkable tradition of invention continues.

Now you can deliver the very latest advances in Chinese science and technology to your patrons, full text via the Web.

Millions of articles from thousands of academic journals and newspapers, even dissertations/theses.

With a surprising number of articles and dissertations printed in English. Academic subscriptions ranging from site licenses to specialized subjects.

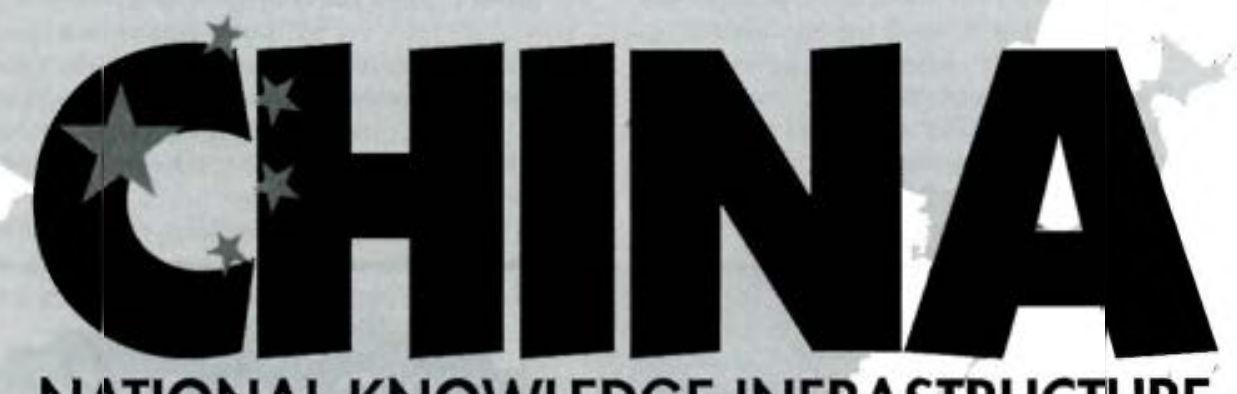

NATIONAL KNOWLEDGE INFRASTRUCTURE

Because new technologies and scientific information

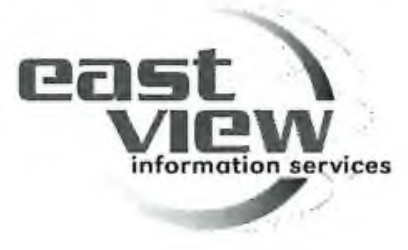
often arise in unexpected places.

\section{china.eastview.com}

1 paper 105 AD, moveable type 1045 AD. 